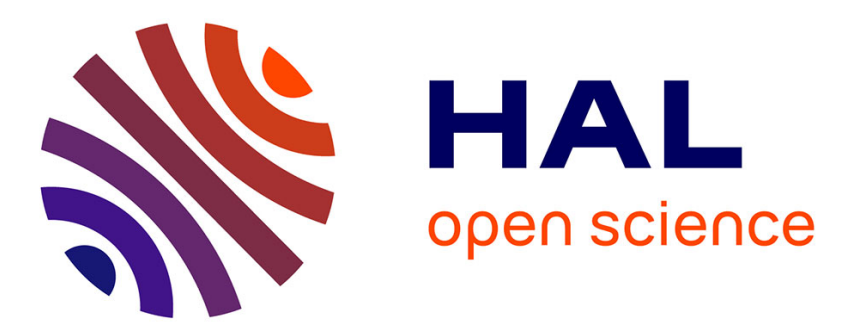

\title{
Simone Lovera-Bilderbeek, 2019, Agents, assumptions and motivations behind REDD+: creating an international forest regime
}

Véra Ehrenstein

\section{- To cite this version: \\ Véra Ehrenstein. Simone Lovera-Bilderbeek, 2019, Agents, assumptions and motivations behind REDD+: creating an international forest regime: Glos, UK, Edward Elgar Publishing, 280 pp.. Re- view of Agricultural, Food and Environmental Studies, 2019, 100 (1-4), pp.149-152. 10.1007/s41130- 019-00094-8 . hal-03006585}

\section{HAL Id: hal-03006585 \\ https://hal.science/hal-03006585}

Submitted on 16 Nov 2020

HAL is a multi-disciplinary open access archive for the deposit and dissemination of scientific research documents, whether they are published or not. The documents may come from teaching and research institutions in France or abroad, or from public or private research centers.
L'archive ouverte pluridisciplinaire HAL, est destinée au dépôt et à la diffusion de documents scientifiques de niveau recherche, publiés ou non, émanant des établissements d'enseignement et de recherche français ou étrangers, des laboratoires publics ou privés. 


\section{Simone Lovera-Bilderbeek, 2019, Agents, assumptions and motivations behind REDD+: creating an international forest regime}

\section{Glos, UK, Edward Elgar Publishing, 280 pp.}

\section{Véra Ehrenstein ${ }^{1}$}

Published online: 11 November 2019

C) INRA and Springer-Verlag France SAS, part of Springer Nature 2019

Within the United Nations negotiation process dedicated to climate change, creating incentives to reduce emissions from deforestation and forest degradation in developing countries (REDD ${ }^{1}$ ) has been, for nearly 10 years, a central topic of discussion. Forests absorb and store massive quantities of carbon and play an essential part in the regulation of the Earth's climate. The idea with REDD+ is to radically transform the valuation of tropical forests, by rewarding emissions reductions as a proxy for the climatic service they provide. Recently, several publications in law, politics and economics have attempted to take stock of this experiment in global environmental governance (e.g. Lyster et al. 2013; Voigt 2016; Angelsen et al. 2018). Simone LoveraBilderbeek's book features among these attempts. Based on an extensive literature review, a series of interviews and her own first-hand experience, the author develops a rich analysis of the multifaceted phenomenon known as REDD+.

The task is not easy. The contours of REDD+ are still unclear. It is, first and foremost, a set of methodological requirements that developing country governments can, voluntarily, decide to comply with, in order to benefit from result-based payments financed, voluntarily, by developed country governments. But REDD+ is more than international guidance painstakingly agreed on at United Nations meetings. The acronym is also used to describe rural development programmes financed by multilateral funds under the management of the World Bank, expert support in forest inventory provided by the Food and Agriculture Organization and small-scale conservation projects initiated by transnational organisations. Outside international conference centres, REDD+ has hybridised with already existing, sometimes long-standing, activities

\footnotetext{
${ }^{1}$ REDD stands for "reducing emissions from deforestation and forest degradation" and the + refers to "the role of conservation, sustainable management of forests and enhancement of forest carbon stocks in developing countries".
}

Véra Ehrenstein

vera.ehrenstein@ucl.ac.uk

1 Institute of Advanced Studies, University College London, London, UK 
in the fields of overseas aid and forest conservation. Even within the confines of United Nations policy-making, the contours of REDD+ remain negotiable. The Paris Agreement includes an article on the topic and discussions are ongoing on whether and how this might translate into further decisions and give more consistency to the voluntary rules. Lovera-Bilderbeek's book can thus be read as an intervention in this political process.

Throughout the book, the author oscillates between factual description, theoretical analysis and political warning. Such a mix of genres is quite common in the protean REDD+ literature, wherein the boundary between author and actor tends to get blurred. This is not so surprising in the field of international relations. Yet, I would like to dwell a little longer on this point here and provide some further insights into REDD+, based on my own experience researching this topic. The consensus-based decision-making process on REDD+ has been open to inputs, not only from various national delegations but also from environmental organisations, human rights activists, and experts and think tanks of all kinds. This relatively inclusive debate has encouraged the proliferation of commentators expressing opinions in academic articles, blog posts and technical reports. Like LoveraBilderbeek's book, such a body of work aims to have effect on the political process it describes. Furthermore, REDD+ is still promissory. The international result-based payment mechanism that was initially envisioned does not exist (yet). Therefore, when REDD+ is talked about in the literature, a shift often occurs from discussing the scattered reality of REDD+—a set of non-legally binding texts, myriads of pledges, commitments and announcements, and some activities implemented here and there, of which it is difficult to get a reliable overview-to speculating on its potential developments, whether these are considered to be positive or negative. The existence of what could become a new international forest regime is still under negotiation. It results that the tension between "analysing what is" and "arguing what should be" is constitutive of the literature on REDD+.

To frame the rather elusive phenomenon of REDD+ for her analysis, LoveraBilderbeek mobilises a theoretical toolbox from the study of global governance (chapter 2). The first half of the book focuses on what the author terms "the agents" of/in REDD+ and explores "the agency of governments" (chapters 3) and "the agency of non-State actors" (chapter 4). The author here provides the reader with some insights into the making of REDD+ within the United Nations negotiation process. Her analysis foregrounds the central role of a few countries otherwise rather marginal on the international scene. She recalls that delegates from Papua New Guinea and Costa Rica were instrumental in building a political coalition around the idea, and that the government of Norway made large funds available to translate the idea into actions, including by institutionalizing the new coalition into a small organization located in New York. Lovera-Bilderbeek's account of the way in which the proposal to reduce tropical deforestation was put on the United Nations agenda illustrates the representational problem associated with the negotiation, where professionalised negotiators speak on behalf of nation-states they have little connection to. This representational problem, the author further argues, also concerns transnational conservation organisations. Despite claiming that they work with local communities, these organisations headquartered in Europe and the USA can hardly represent the interests of forestdwelling people (more on this below). 
As she discusses the agency of non-state actors involved in REDD+, LoveraBilderbeek mentions the World Bank and its multilateral vehicle, the Forest Carbon Facility Partnership. The latter has provided financial support to nearly 50 countries willing to engage in so-called REDD+ readiness activities, such as consultations and awareness raising initiatives. Another key non-state protagonist foregrounded in the book is the Centre for International Forestry Research (CIFOR). The recipient of a large grant from the Norwegian government, the CIFOR, has contributed to document, through a critical-reformist lens, the evolution of REDD+. Numerous policy-oriented studies have been published by the centre and showcased during side events organised at every United Nations negotiation meetings. By highlighting both the readiness funding distributed via the World Bank and CIFOR's public engagement activities, the book suggests that REDD+ might primarily be a discursive artefact that is drawing political attention to the conservation of tropical forests.

The second half of the book unpacks the three main "assumptions behind REDD+ " (chapter 5), effectiveness, efficiency and equity and examines to which extent these assumptions hold in practice (chapters $6,7,8$ ). Here, the author introduces the reader to multiple arguments for and against REDD+ that have been exchanged in the scholarly debate. As she discusses the effectiveness of REDD+, Lovera-Bilderbeek evokes the challenges of monitoring forest cover, quantifying carbon stocks and establishing reference levels, against which future deforestation rates, and associated carbon loss, could be compared to obtain emissions reductions. Calculating results to be rewarded, in order to transform the valuation of tropical forests and keep them standing, raises many difficult questions regarding the uncertainty of any estimates, the displacement of deforestation (leakage) and the fact that trees eventually die (nonpermanence). While these methodological concerns should require the expertise of ecologists, remote sensing specialists and forestry engineers, Lovera-Bilderbeek shows that the main proponents of REDD+, in particular among negotiators, have instead background experience in economics, management and business administration. As a result, the effectiveness of REDD+ is weak. And even though the conservation organisations that are active on the topic might have the relevant expertise, she further argues that a narrow focus on the forest sector is unable to address what, in many regions of the world, drives deforestation, namely agricultural expansion (beef, soy, palm oil, etc.).

For Lovera-Bilderbeek, the assumed economic efficiency of REDD+ appears debatable too. She first explains that REDD+ was promoted by promising quick and cheap emissions reductions. She then examines what the opportunity costs might be of deciding to protect a forested area, which could have been converted into pastures, or a plantation, and used for rather lucrative commercial activities. The assumption of low opportunity costs clearly does not hold. Furthermore, the result-based funding system envisioned in REDD+ potentially entails substantial transaction costs. The author explains that large parts of the REDD+ funding distributed so far have been spent on meetings and consultancies. In place of emissions reductions, REDD+ is financing intermediaries and experts of all sorts. As for the source of funding, it was widely expected that REDD+ would be financed through an offsetting mechanism. Emissions reductions would be estimated, monetized, sold and bought, including by private sector actors. In contrast, most of the resources made available until now have been drawn from overseas aid, especially from Norway's budget generated by its oil economy. 
Moving on to equity considerations, Lovera-Bilderbeek recalls that United Nations decisions include a series of environmental and social safeguards. She insists on the importance of addressing governance issues in order to ensure that the protection offered on paper to indigenous groups and local communities materialises on the ground. She considers that allowing forest dwellers to obtain secure land tenure rights is an essential step towards preserving forests and their climatic service. This is probably where the political engagement of the author is clearest. She comes back here to the representational problem alluded to above, as she explains that transnational conservation organisations have come to be the main implementers of REDD+ projects, often at the expense of the people living in and with these forests. The conclusion of the book further develops this tension by emphasising the need to disentangle the broad category of civil society and distinguish between stakeholders and rightsholders.

The book, thus, touches on many essential aspects of REDD+, understood here as yet another attempt to establish an international forest regime. Because REDD+ is still in the making, it is surrounded by indeterminacy. This is revealed in the book through the divergent views expressed by Lovera-Bilderbeek's interviewees. But the author does not provide contextual information when she refers to these opinions. The book only contains an appendix summarising the institutional actors of which representatives have been interviewed. Preserving anonymity can be vital when one works with interview material. It, nevertheless, seems important to situate interviewees' vantage points when, like here, the topic at issue is a matter of disagreement. Similarly, the numerous publications cited in the book are not contextualised and the positioning of this abundant literature at the interface between academic work and policy prescription is left unacknowledged. Finally, as Lovera-Bilderbeek seeks to understand why actors as diverse as developing and developed governments, conservation organisations and research institutions have engaged with REDD+, her analysis falls back on a rather simplistic explanation, wherein the economic interest is the central motivation of any actions. The focus on financial resources is, expectedly, strong in REDD+. After all, the idea is to create a result-based payment mechanism. It is, however, slightly reductive to consider that for government officials, conservationists and researchers, getting access to funding is an end in and of itself, although one cannot deny that securing and managing funds has come to take up a lot of space in development aid and research.

To conclude, this book provides a rich overview of the multifaceted phenomenon referred to as REDD+ and invites further analysis of what might become (or not) a new international forest regime.

\section{References}

Angelsen, A., Martius, C., De Sy, V., Duchelle, A. E., Larson, A. M., \& Thuy, P. T. (Eds.). (2018). Transforming REDD+: Lessons and new directions. Bogor: Centre for International Forestry Research.

Lyster, R., MacKenzie, C., \& McDermott, C. (Eds.). (2013). Law, Tropical Forests and Carbon: The case of $R E D D+$. Cambridge: Cambridge University Press.

Voigt, C. (Ed.). (2016). Research Handbook on REDD+ and International Law. Cheltenham: Edward Elgar Publishing.

Publisher's note Springer Nature remains neutral with regard to jurisdictional claims in published maps and institutional affiliations. 